Canadian Science Publishing

Canadian Journal of Physiology and Pharmacology Revue canadienne de physiologie et pharmacologie

\title{
Hepatoprotective Effect of Blocking N-Methyl-D-Aspartate Receptors in Male Albino Rats Exposed to Acute and Repeated Restraint Stress
}

\begin{tabular}{|r|l|}
\hline Journal: & Canadian Journal of Physiology and Pharmacology \\
\hline Manuscript ID & cjpp-2016-0556.R1 \\
\hline Danuscript Type: & Article \\
\hline Complete List of Authors: & $\begin{array}{l}\text { Amin, Shaimaa; Department of Medical Physiology, Faculty of Medicine, } \\
\text { Cairo University } \\
\text { El-Aidi, Ahmed ; Quality Assurance Department, Hikma Pharmaceuticals } \\
\text { Zickri, Maha; Department of Histology, Faculty of Medicine, Cairo } \\
\text { University } \\
\text { Rashed, Laila; Department of Biochemistry, Faculty of Medicine, Cairo } \\
\text { University } \\
\text { Hassan, Sherif ; Department of Anatomy, Faculty of Medicine, Cairo } \\
\text { University; California University of Science and Medicine, School of } \\
\text { Medicine, Department of Medical Education }\end{array}$ \\
\hline Keyword: & \begin{tabular}{l} 
Acute stress repeated stress, Restraint, liver, memantine \\
\hline
\end{tabular} \\
\hline
\end{tabular}

\section{SCHOLARONEm}

Manuscripts 


\title{
Hepatoprotective Effect of Blocking N-Methyl-D-Aspartate Receptors in Male Albino Rats Exposed to Acute and Repeated Restraint Stress
}

\author{
Authors \\ Shaimaa Nasr Amin, MD. \\ Department of Medical Physiology, Faculty of Medicine, Cairo University, Egypt
}

Ahmed Amro El-Aidi

Quality Assurance Department, Hikma Pharmaceuticals, Egypt

Maha Baligh Zickri, MD.

Department of Histology, Faculty of Medicine, Cairo University, Egypt.

Laila Ahmed Rashed, MD.

Department of Biochemistry, Faculty of Medicine, Cairo University, Egypt

Sherif Sabry Hassan, MD, Ph.D.

Department of Anatomy, Faculty of Medicine, Cairo University, Egypt.

California University of Science and Medicine, School of Medicine, Department of Medical Education, Colton, CA, USA.

\section{CORRESPONDING AUTHOR:}

\section{Shaimaa Nasr Amin, MD}

Department of Medical Physiology, Faculty of Medicine, Cairo University, Egypt

E-mail: shaimaa599@yahoo.com

Telephone: $+201142244442 /+201111777956$

Fax: $+202-23682030$ 


\begin{abstract}
:
Stress affects multiple organs in the body in addition to the brain including the liver. We aimed to assess the effects of blocking N-methyl-D-aspartate (NMDA) glutamate receptors by memantine on the liver in acute and repeated restraint stress. Forty two male albino rats divided into seven groups; control, Acute restraint stress (ARS), ARS+memantine, repeated restraint stress, repeated restraint +memantine and positive control groups. We measured serum iron, zinc, alanine transferase and Aspartame transferase, hepatic malondialdehyde, tumor necrosis factor-alpha (TNF- $\alpha$ ), glutathione peroxidase, Superoxide dismutase, metallothionein content, zinc transporter ZRT/IRT-like Protein 14 mRNA expression, hepcidin expression. We had a histopathological evaluation by histological staining and immunostaining for glial fibrillary acidic protein and synaptophysin expression as markers of hepatic stellate cells (HSCs) activation. Both ARS and repeated stress increased markers of hepatic cell injury, oxidative stress, and HSCs activation. Blocking NMDA by Memantine offered hepatoprotective effect in acute and repeated restraint stress and decreased hepatic cell injury, oxidative stress, and HSCs activation.
\end{abstract}

\title{
KEYWORDS:
}

Acute stress repeated stress, Restraint, liver, memantine 


\section{-INTRODUCTION:}

Stress changes the structure and composition of the body as signs of damage with some modifications occurs as an adaptive defensive reaction (Selye 1955). Glucocorticoids secreted during stress affect the basal release of glutamate in the brain (Popoli et al. 2011).Also, acute stress enhances glutaminergic transmission through Nmethyl-D-aspartate (NMDA)- and $\alpha$-amino-3-hydroxy-5-methyl-4-isoxazolepropionic acid receptor (AMPA) glutamate receptors (Yuen et al. 2011). Furthermore', glutamate is involved in control of the hypothalamicpituitary-adrenal (HPA) axis (Zelena et al. 2005). Restraint stress affects multiple organs in addition to the brain including the liver (Muqbil and Banu 2006). Both acute and chronic stress can cause liver injury due to misalignments in HPA axis and the change in the glucocorticoid plasma level. Acute stress increases the degradation of hepatic glycogen, on the other hand; chronic stress causes hepatocyte disorganization, compressed sinusoids (Vásquez et al.2014), and decreases the level of triglycerides (Czech et al. 2013).

There are peripheral glutamate receptors in the liver; as hepatocytes express mGlu5 receptors and activation of these receptors by endogenous glutamate facilitates the development of hypoxic damage (Storto et al. 2000). Nmethyl-D-aspartate (NMDA) receptors are well studied in acute injury due to hyperammonemia in hepaticencephalopathy as ammonia stimulates astrocytes that activate NMDA receptors. The stimulation of ammonia-induced NMDA receptors lowers antioxidant enzyme activity and increases the oxidative stress (Görg et al. 2013).

In the current study, we explored the effects of acute and repeated restraint stress on the liver and the impact of blocking NMDA receptors by the memantine (the uncompetitive NMDA receptor antagonist) on the markers of hepatocellular injury, oxidative stress, and hepatic stellate cells (HSCs) activation.

\section{-METHODS:}

\section{I-Experimental Animals:}

The experimental procedures, animal handling, sampling, and scarification were done according to the Guide for the care and use of laboratory animals, Eighth Edition (2011) and were approved by Ethical Committee of Physiology Department, Faculty of Medicine, Cairo University. Forty two male Wistar albino rats, 3-4 months old weighing about 100-150 gm., constituted the animal model for this study. All animals were provided with 
standard laboratory chow and water, housed in cages (3 rats/cage), habituated to laboratory environment for one week and divided into the following groups (6 rats/group):

-Group I (control): Received distilled water per oral (p.o).

-Group II; acute restraint stress (ARS) group. Exposed to ARS through restraining the rats by tightly tying all four limbs to a grid using a quartz-pasted tape (Kumar et al. 2010) for 2 hours (10:00 a.m. to 12:00 p.m.) (Amin et al. 2015; Yuen et al. 2013).

-Group III (Memantine+ ARS group): Received Memantine (20 mg/kg, p.o) (Quan et al. 2011), obtained as commercial tablets (Memexa tablet, $10 \mathrm{mg} /$ tablet, Copad Egypt for Trade and Pharmaceutical Industries, Egypt). Group IV (Repeated restraint stress group) Exposed to repeated restraint stress through restraining the rats 2 hours daily for seven days (Amin et al. 2015; Yuen et al. 2013).

-Group V (Memantine + Repeated restraint stress group) Treated by Memantine and exposed to repeated restraint stress-Group VI (Memantine group) Treated by Memantine. This group further subdivided into:

Group VIa: received Memantine for eight days.

Group VIb: received Memantine for 15 days.

In group III and V: The pretreatment time by memantine started one week before stress exposure (with the start of habituation to experimental environment) and treatment continued throughout the experimental period until scarification. At the end of the experimental period of stress induction and drug administration animals were anesthetized by ether inhalation, and blood samples collected from retro-orbital venous sinuses for biochemical measurement of serum iron, zinc, alanine transferase (ALT) and Aspartame transferase (AST). Then liver were specimens removed by a ventral midline incision for biochemical measurements: hepatic malondialdehyde (MDA), tumor necrosis factor- $\alpha$ (TNF- $\alpha$ ), glutathione peroxidase (GPX), Superoxide dismutase (SOD), metallothionein (MT) content, zinc transporter ZRT/IRT-like Protein 14 (ZIP14) mRNA expression and hepcidin expression. In addition to histopathological evaluation by histological staining and immunostaining for glial fibrillary acidic protein (GFAP) and synaptophysin expression. 


\section{II-Biochemical Measurements:}

\section{A) Measurement of serum iron ( $\mathrm{Fe})$ and zinc $(\mathrm{Zn})$ :}

Serum concentrations of $\mathrm{Fe}$ and $\mathrm{Zn}$ measured on a Hitachi 902 biochemistry analyzer. A colorimetric ferrozinebased assay was used to quantify iron in serum modified from Riemer et al. (2004). Serum samples initially mixed with equal volumes of $1.4 \mathrm{~mol} / \mathrm{L} \mathrm{HCl}$ and $4.5 \% \mathrm{KMn}_{4}$, and then ferrozine iron-detection reagent (6.5 mmol/L ferrozine, $6.5 \mathrm{mmol} / \mathrm{L}$ neocuproine, $2.5 \mathrm{~mol} / \mathrm{L}$ ammonium acetate, and $1 \mathrm{~mol} / \mathrm{L}$ ascorbic acid) followed by a 30-min incubation and then absorbance measured at $550 \mathrm{~nm}$. The concentration was calculated by comparing absorbance to a standard curve of $\mathrm{FeCl}_{3}$ standards.

Serum zinc was estimated by 2-(5-Brom-2-pyridylazo)-5-(N-propyl-N-sulfopropylamino)-phenol colorimetric method using kit supplied by Spinreact SA Spain. The estimation of zinc is based on principle in which zinc react with specific complexant 5-Br PAPS forms a stable color complex. The color intensity is proportional to the amount of zinc present in the sample (Johnsen and Eliasson 1987).

\section{B) Determination of liver functions}

Serum ALT and AST were determined enzymatically using commercially available kits (Bioclin, Santa Coloma, Spain).

\section{C) Measurement of MDA}

Tissue MDA was determined using the thiobarbituric acid reactive substance assay, according to Wills (1987).Briefly; a tissue specimen of $0.1 \mathrm{~g}$ was homogenized in $0.15 \mathrm{~mol} \mathrm{KCl}$ at a ratio of $1-9 \mathrm{ml}$ with a glass homogeniser. One volume of homogenate was mixed with two volumes of a stock solution of $20 \% \mathrm{w} / \mathrm{v}$ trichloroacetic acid, $0.375 \% \mathrm{w} / \mathrm{v}$ thiobarbituric acid and $0.25 \mathrm{~mol}$ hydrochloric acid. The solution was heated for $15 \mathrm{~min}$ in a boiling water bath. After cooling, the precipitate was removed by centrifugation at $1000 \mathrm{~g}$ for $10 \mathrm{~min}$. The absorbance of the clear supernatant was determined at $535 \mathrm{~nm}$ and MDA concentration calculated using the standard curve. 


\section{D) Determination of GPx activity}

The activity of GPx was evaluated with GPx detection kit according to the manufacturer's instructions. GPx catalyzes the oxidation of glutathione by cumene hydroperoxide. In the presence of glutathione reductase and $\mathrm{NADPH}$, the oxidized glutathione immediately converted to the reduced form with a concomitant oxidation of $\mathrm{NADPH}$ to NADP+. The decrease in absorbance was measured spectrophotometrically against blank at $340 \mathrm{~nm}$ (Ellman 1959).

\section{E) Measurement of SOD}

SOD activity in tissue homogenate measured through the inhibition of nitroblue tetrazolium reduction by $\mathrm{O}_{2}^{-}$ generated by the xanthine/xanthine oxidase system. One SOD activity unit is defined as the enzyme amount causing 50\% inhibition in $1 \mathrm{~mL}$ reaction solution per milligram tissue protein and the result expressed as $\mathrm{U} / \mathrm{mg}$ protein (Misra and Fridovich 1972).

\section{F) Measurement of TNF- $\alpha$}

Serum TNF- $\alpha$ is measured by using enzyme-linked immunosorbent assay (ELISA) \{quantikine R\&D system USA \} according to the manufacturer`s instructions (Maskos et al. 1998).

G) Gene expression of metallothionin, ZIP14 and hepcidin by real-time polymerase chain reaction (PCR)

\section{a. Total RNA extraction}

Total RNA was extracted from tissues using TRIzol method according to the manufacturer's protocol. In brief, RNA was extracted by homogenization in TRIzol reagent (Invitrogen, Life Technologies, USA).The homogenate then incubated for $5 \mathrm{~min}$ at room temperature. A 1:5 volume of chloroform added, and the tube was vortexed and centrifuged at $12000 \mathrm{~g}$ for $15 \mathrm{~min}$. The aqueous phase was isolated, and the total RNA precipitated with absolute ethanol. After centrifugation and washing, the total RNA finally eluted in $20 \mu \mathrm{L}$ of the RNase-free water. The RNA concentrations and purity measured with an ultraviolet spectrophotometer (Livak and Schmittgen 2001). 


\section{b. Complementary DNA (cDNA) synthesis}

The cDNA was synthesized from $1 \mu \mathrm{g}$ RNA using SuperScript III First-Strand Synthesis System as described in the manufacturer's protocol (Invitrogen, Life Technologies). In brief, one $\mu$ g of total RNA mixed with $50 \mu \mathrm{M}$ oligo (dT)20, $50 \mathrm{ng} / \mu \mathrm{L}$ random primers, and ten $\mathrm{mM}$ dNTP mix in a total volume of $10 \mu \mathrm{L}$. The mixture incubated at $56{ }^{\circ} \mathrm{C}$ for $5 \mathrm{~min}$, then placed on ice for $3 \mathrm{~min}$. The reverse transcriptase master mix containing $2 \mu \mathrm{L}$ of $10 \times \mathrm{RT}$ buffer, $4 \mu \mathrm{L}$ of $25 \mathrm{mM} \mathrm{MgCl} 2,2 \mu \mathrm{L}$ of $0.1 \mathrm{M}$ DTT, and $1 \mu \mathrm{L}$ of SuperScript ${ }^{\circledR}$ III RT (200 U/ $\left.\mu \mathrm{L}\right)$ added to the mixture and incubated at $25^{\circ} \mathrm{C}$ for $10 \mathrm{~min}$ followed by $50 \mathrm{~min}$ at $50^{\circ} \mathrm{C}$.

\section{c. Real-time quantitative PCR}

The relative abundance of mRNA species was assessed using the SYBR Green method on an ABI prism 7500 sequence detector system (Applied Biosystems, Foster City, CA). PCR primers (shown in Table 1) designed with Gene Runner Software (Hasting Software, Inc., Hasting, NY) from RNA sequences from GenBank. All primer sets had a calculated annealing temperature of $60^{\circ}$. Quantitative RT-PCR performed in a $25-\mu 1$ reaction volume consisting of 2X SYBR Green PCR Master Mix (Applied Biosystems), $900 \mathrm{nM}$ of each primer and 2-3 $\mu$ l of cDNA. Amplification conditions were $2 \mathrm{~min}$ at $50^{\circ}, 10 \mathrm{~min}$ at $95^{\circ}$ and 40 cycles of denaturation for $15 \mathrm{~s}$ and annealing/extension at $60^{\circ}$ for $10 \mathrm{~min}$. Data from real-time assays were calculated using the v1.7 Sequence Detection Software from PE Biosystems (Foster City, CA). Relative expression of studied gene mRNA was calculated using the comparative $\mathrm{Ct}$ method. All values were normalized to the beta actin gene and reported as fold change over background levels detected in diseases group (Kenneth et al. 2001).

\section{III-Histopathological Measurements:}

The removed liver specimens were fixed in $10 \%$ formol saline for 48 hours. Paraffin blocks were prepared then sections were cut with thickness of $5 \mu \mathrm{m}$ and have been subjected to the following studies:

\section{A) Histological Study:}

a. Hematoxylin and eosin (Kiernan 2001): Stain for the demonstration of the structure of the liver.

b. Masson's trichrome stain (Bancroft and Gamble 2008): Stain for the demonstration of the collagen content of the liver. 


\section{B) Immunohistochemical Study:}

a. GFAP immunostaining (Xiao et al. 2014): Serial sections were cut and taken onto poly-lysine coated slides. Boiling of tissue sections in $10 \mathrm{mM}$ citrate buffer $\mathrm{pH} 6.0$ for 10-20 minutes was performed and then leave to cool at room temperature for $20 \mathrm{~min}$. Wash two times in phosphate buffer saline. Apply primary antibody rabbit polyclonal Ab supplier (LabVision) catalog number (AB5804) and incubate at room temperature in a moist chamber for 60 minutes. The primary antibody used is $50 \mu \mathrm{L}$ diluted. Dilution: 1:1000 using to reduce background and unspecific staining. Apply biotinylated rabbit anti-polyvalent and incubate for 10 minutes at RT in a moist chamber. Incubate with DAB chromogen mixture for 5-15 minutes at RT. Counterstain the slides with Mayer-Haematoxylin for 1-3 minutes. Rat astrocytes and rat neurons are considered positive control specimens which give a brown coloration. Cellular localization is cytoplasmic. On the other hand, one of the liver sections used as a negative control by passing the step of applying the primary antibody.

b. Synaptophysin immunostaining (Tennakoon et al. 2015): Boiling of tissue sections in $10 \mathrm{mM}$ citrate buffer $\mathrm{pH}$ 6.0 for $10-20$ minutes was performed and then leave to cool at room temperature for $20 \mathrm{~min}$. Apply primary antibody rabbit monoclonal Ab supplier (Abcam) catalog number (ab32127) and incubate at room temperature in a moist chamber for 60 minutes. The primary antibody used is $40 \mu \mathrm{L}$ diluted 1:400. Rat astrocytes and rat neurons are considered positive control specimens. Cellular localization is cytoplasmic.

\section{B) Morphometric Study:}

Using Leica Qwin 500 LTD computer-assisted image analysis (Cambridge, UK) assessment of the area of degenerated hepatocytes was performed using interactive measurements menu. Also, the area\% of collagen fibers, that of synaptophysin $+v e$ immunoexpression and that of GFAP+ve immunoexpression were measured using binary mode. The measurements were done in 10 high power fields in experimental groups.

\section{IV- Statistical analysis:}

Quantitative data were summarized as means and standard deviations and compared using one-way analysis-ofvariance (ANOVA). ANOVA was followed by Bonferroni post-hoc test to detect which pairs of groups caused the significant difference. $P$-values $<0.05$ were considered statistically significant (Emsley et al. 2010). Calculations made using SPSS software 21. 


\section{-RESULTS:}

\section{I-Biochemical results:}

\section{As shown in table (2) there are:}

A significant increase ( $p$ value $\leq .05$ ) of serum of ALT and AST in acute and repeated stress groups compared to control. Memantine administration with stress significantly decreased ( $p$ value $\leq .05)$ serum ALT and AST compared to stressed groups that didn't receive the drug, however, levels were significantly increased ( $p$ value $\leq .05)$ compared to control. Serum iron was significantly decreased ( $p$ value $\leq .05$ ) in acute and repeated stress groups compared to control. Memantine therapy with stress exposure resulted in significant increase ( $p$ value $\leq .05)$ in serum iron compared to corresponding stress group, but the serum iron level in these groups still significantly decreased ( $p$ value $\leq .05)$ compared to control group. Furthermore; serum zinc significantly decreased $(p$ value $\leq .05)$ in stressed groups compared to control. Stressed groups treated with memantine showed a significant increase $(p$ value $\leq .05)$ of serum zinc compared to corresponding stress group. In ARS only memantine therapy with stress restored the serum zinc level to normal control level. We also found a significant increase ( $p$ value $\leq .05$ ) of hepatic hepcidin and ZIP14 relative expression in stressed groups compared to control group. Memantine therapy with stress caused a significant decrease ( $p$ value $\leq .05$ ) of hepatic hepcidin and ZIP14 relative expression compared to corresponding stress group, however, the expression still significantly increased ( $p$ value $\leq .05)$ compared to control group. Moreover; there was a significant decrease $(p$ value $\leq .05)$ of hepatic SOD and GPX content in acute and repeated stress groups compared to control. Memantine therapy with stress exposure resulted in significant increase $(p$ value $\leq .05)$ of hepatic SOD and GPX compared to corresponding stress group, but the hepatic SOD and GPX in these groups still significantly ( $p$ value $\leq .05$ ) decreased compared to control group.

There was a significant increase $(p$ value $\leq .05)$ of hepatic TNF- $\alpha$ and MDA content in stressed groups compared to control. Memantine therapy with stress caused a significant decrease ( $p$ value $\leq .05)$ of hepatic TNF- $\alpha$, and MDA compared to corresponding stress group, however, it didn't restore the values back to normal.

We also showed a significant increase $(p$ value $\leq .05)$ of hepatic metallothionin relative expression in stress groups compared to control. Memantine therapy with stress caused a significant increase ( $p$ value $\leq .05)$ of hepatic 
metallothionin relative expression compared to corresponding stress group; however only in ARS memantine restored hepatic metallothionin relative expression to control level.

\section{II-Histopathological results:}

Examination of H\&E stained liver sections of ARS group revealed large and small areas of lost architecture (Fig.1a). These areas contained many pale hepatocytes and multiple hepatocytes with basophilic cytoplasm around congested veins. Multiple Kupffer cells were noticed (Fig.1b). In ARS+Memantine group; occasional small areas found with lost architecture. Congested veins were seen in and around the mass (Fig.1c). These areas demonstrated multiple vacuolated hepatocytes with dark nuclei and some hepatocytes with pale cytoplasm in addition to congested veins in and around the masses (Fig.1d). In repeated stress group; extensive areas of lost architecture were found, each constituting a mass of residual hepatocytes (Fig.2a). Cellular debris was detected surrounding a mass of hepatocytes with nuclear margination (Fig.2b). In repeated stress+memantine group; only localized areas of lost architecture were noticed (Fig.2c). In Memantine groups normal architecture was seen, only congested veins were detected (Fig.2d).

In Masson's trichrome stained sections, control sections revealed dense collagen fibers in portal areas (Fig.3a). In ARS group, some portal areas were found where the dense collagen fibers were extending among the surrounding hepatocytes (Fig.3b). In ARS +memantine group; thick collagen fibers localized to the portal areas (Fig.3c). In repeated stress group, extensive collagen fibers were seen in multiple portal areas extending among the hepatocytes. Obviously, congested veins were evident (Fig.3d). In repeated stress+memantine group; dense collagen fibers observed in portal areas with minimal extension among the surrounding hepatocytes (Fig.3e). In memantine group, dense collagen fibers appeared restricted to some portal areas (Fig.3f). Less congested veins were evident in repeated stress + memantine, in addition to memantine groups (Figs.3e and 3f).

\section{*Immunohistochemical Results:}

\section{A) GFAP immunostaining}

Negative immunostaining noticed in liver sections of control and memantine group (Figs.4a and 4f). In ARS group, multiple +ve cells were detected among the hepatocytes, while in ARS + memantine group only fewer +ve cells were observed compared to the previous group (Figs.4b and 4c). Many +ve cells were apparent in repeated 
stress group compared to ARS group, while in ARS + memantine group only some +ve cells were evident compared to RS group (Figs. 4d and 4e).

\section{B) Synaptophysin immunostaining}

Negative immunostaining was noticed in liver sections of control and memantine groups (Figs.5a and 5f). In ARS group, multiple +ve cells detected among the hepatocytes surrounding some portal areas, while in ARS + memantine group only fewer +ve cells were observed compared to the previous group (Figs.5b and 5c). More numerous +ve cells were apparent in repeated stress group surrounding multiple portal areas compared to ARS group, while in repeated stress + memantine group only some +ve cells were evident compared to repeated stress group (Figs. 5d and 5e).

\section{C) Morphometric Results:}

\section{As shown in Table (3):}

\section{i-Area of foci of lost architecture and Area\% of collagen fibers:}

The mean area $\left(\mu^{2}\right)$ of foci was measured in hematoxylin and eosin stained liver sections. In ARS and repeated stress groups, a significant increase $(p<0.05)$ was recorded compared to control. On the other hand, a significant increase $(p<0.05)$ was found in repeated stress group compared to ARS group. Memantine administration with stress significantly decreased area of foci with lost architecture compared to corresponding stress group.

\section{ii-Area\% of collagen fibers:}

The mean area\% of collagen fibers was measured in Masson's trichrome stained sections. In ARS and repeated stress groups, a significant increase $(p<0.05)$ was recorded compared to control, Memantine administration with stress significantly decreased area $\%$ of collagen fibers compared to corresponding stress group.

\section{iii-Area \%of GFAP and Synaptophysin immunoexpression:}

The mean area \% of GFAP and synaptophysin immune expression was measured in GFAP immunostained liver sections. In ARS and repeated stress groups, a significant increase $(p<0.05)$ was recorded compared to control. 
On the other hand, a significant increase $(p<0.05)$ was found in repeated stress group compared to ARS group. Memantine therapy significantly decreased GFAP and synaptophysin expression compared to corresponding stress groups.

It worth noting that the $\%$ change for most of the measured biochemical and histological parameters revealed that the insult was more in repeated stress group as shown by higher $\%$ change compared to control. Percent change in groups treated by memantine with stress exposure -compared to corresponding stress group- was higher in repeated stress+memantine group than ARS+memantine group for most of the measured biochemical and histological parameters.

\section{-DISCUSSION:}

Restraint stress increases the risk of many diseases due to oxidative damage to DNA, proteins, and lipids, which are catalyzed by reactive oxygen species (Buijsse et al. 2007). The liver is one of the affected organs by the negative impact of restraint stress exposure and in this work we investigated the effect of memantine administration on the markers of hepatic cell injury, oxidative stress, and HSCs activation.

We have showed previously that ARS and repeated stress increased serum cortisol, IL-6 and TNF-a compared to control group and Memantine therapy with exposure to ARS or repeated restraint stress decreased serum cortisol, IL-6 and TNF-a compared to ARS and repeated restraint groups respectively (Amin et al 2015).

Reactive oxygen species (ROS) generated during cell metabolism have harmful effects on cells (Tiebosch 2014). Pre-oxidation of lipid by free radicals produce end product called MDA which is a marker for oxidative stress (Wang et al.2015). In accordance with our results; Xu et al. (2006) showed that MDA level increased in mice by restraint stress. MDA also increased by thermal stress (Chien and Hwang 2001).

The free radical scavengers such as SOD and GPx detoxify the reactive oxygen species to protect the cell, prevent peroxidation of lipid, hepatic inflammation, fibrosis and necrosis (Adikwu and Deo 2013).

The Glutamate release increases by stress (Musazzi et al. 2015) and it activates the reactive oxygen species sources (Basuroy et al. 2013). Also, SOD mimetic decreased the release of pathological glutamate (Dohare et al. 2014). Moreover; the activities of GPx decreased, and MDA increased in liver after administration of glutamate precursor $\alpha$-ketoglutarate in young pigs (Wang et al. 2015). 
TNF- $\alpha$ is one of proinflammatory cytokines. When proinflammatory cytokines are added to cultured astrocytes glutamate transporters and capacity of glutamate uptake decreased (Knecht et al. 1997). TNF-- $\alpha$ increased glutamate by increasing and moving glutaminase expression from mitochondria to cytosol and extracellular space (Ye et al. 2013).

Hepcidin is a peptide hormone synthesized by liver and control the iron metabolism by control the absorption of iron from duodenum (Nicolas et al. 2001). Decrease hepcidin in mice led to increasing liver iron content (Ramos et al. 2011). In agreement with our results Zhao et al. (2008) showed a decrease of hepatic iron content and upregulation of hepcidin expression with psychological stress. Stress decreases both serum and bone marrow iron (Wei et al. 2008) and decreases iron absorption (Chen et al.2009). Also, Increase of the endogenous mediator obtained from leukocytes decreases serum iron (Pekarek and Beisel 1971).

The glutamate secretion in cultured lens and neuronal cells was increased by iron which increases the activity of cytosolic aconitase enzyme. That enzyme is iron dependent which helps conversion of citrate to isocitrate increasing glutamate secretion (McGahan et al. 2005). Furthermore; iron overload leads to release of glutamate in ischemic rat's brain (Millán et al. 2008) while, iron deficiency in newborn rats decreases the glutamate dehydrogenase and glutamate decarboxylase (Batra and Seth 2002).

Zhao et al. (2008) observed up-regulation of hepcidin and down-regulation of ferroportin. After psychological stress exposure; IL-6 increased through a mechanism independent of tissue injury or inflammation, while through the activation of the HPA axis and sympathetic nervous system (Kageyama et al. 2007).

Zinc is necessary for normal liver function; and the liver plays a central role in $\mathrm{Zn}$ homeostasis (Krebs and Hambidge 2001). ZIP14 is a transmembrane metal ion transporter that is abundantly expressed in the liver, heart, and pancreas. ZIP 14 comprises transmembrane zinc transporters that pump extracellular Zn2+ into the cell (Jeong and Eide 2013) and mediates the uptake of non-transferrin-bound iron, a form of iron that appears in the plasma during pathologic iron overload (Zhao et al. 2010).

Previous studies reported increase of liver zinc concentration and ZIP14 expression by restraint stress (Ohashi et al.2008). Similar to our results; Tian et al. (2014) observed decreased serum zinc level and increased ZIP14 mRNA expression seven days after stress exposure. Zip14 expression is up-regulated during restraint stress through IL-6 (Liuzzi et al. 2005). 
Oxidative or nitrosative stress can cause a release of zinc from proteins containing zinc fingers and its redistribution, altering the functions of those proteins. MT belongs to the principal maintainers of the zinc pool and, also, can be associated with scavenging of free radicals. The cluster structure of Zn-MT provides a chemical basis by which the cysteine ligand can induce oxidoreductive properties (Maret and Vallee 1998).

As a consequence of tissue damage, HSCs, as well as other extracellular matrix - producing cells, undergo a process of activation toward a phenotype characterized by increased proliferation, motility, contractility, and synthesis of extracellular matrix components. HSCs express vimentin, desmin, alpha- smooth muscle actin $(\alpha-$ SMA) glial fibrillary acidic protein, nestin, neural cell adhesion molecule and synaptophysin (Cassiman et al. 2001). Activation of HSCs is regulated by several soluble factors, including cytokines, chemokines, growth factors, and products of oxidative stress (Greenwel et al. 1994).

GFAP is a member of the cytoskeletal protein family (Eng et al. 2000) it maintains the structure of the cell (Hassan et al. 2014). GFAP expressed in liver by HSCs which founded between hepatocytes and sinusoidal endothelial cells (Stewart et al. 2014). GFAP increased in human hepatitis that makes it able to be used in diagnosis of early hepatic fibrosis in chronic hepatitis C (Hassan et al. 2014). Synaptophysin also expressed by HSCs and is a marker of HSCs activation (Gard et al. 1985).

NMDA receptors blocker memantine has been shown in previous studies to decrease the oxidative stress by blocking the excessive calcium entry mediated by NMDA receptors, not by a direct effect (Liu et al. 2013). Memantine also decreased the glycogen depletion in rats exposed to cold stress (Ferreira et al. 2011). This effect may be explained by its antioxidant properties (Lupp et al. 2003) and decreased TNF- $\alpha$ and IL-6 in rats exposed to acute and repeated restraint stress (Amin et al. 2015).

\section{-CONCLUSIONS AND RECOMMENDATIONS:}

Both acute and repeated stresses have adverse effects on the liver as demonstrated from markers of oxidative stress, hepatic cell injury, and HSCs activation. Memantine that blocks NMDA glutamate receptors decreased the effects of restraint stress on the liver, and its protective effect was more prominent in ARS especially for serum zinc and hepatic MT expression. Further, in vitro studies are required to specify if the protective effect of memantine on the liver occurred as a result of blocking central NMDA receptors in the brain and HPA axis or through a peripheral mechanism on the liver. Also, Further studies with longer duration of therapy are 
recommended to evaluate the approximate time needed to revert the insult induced by repeated restraint stress and makes the measured parameter closer to those in the control group.

\section{- ACKNOWLEDGEMENTS:}

We would like to thank Mohamed Mostafa Ali, Yasser Mahmoud Attia, and Tarek Mamdouh for their kind help during specimens collection and tissue preparation for histopathological evaluation.

\section{-CONFLICT OF INTEREST:}

There is no conflict of interest.

\section{-REFERENCES:}

Academies NRCoN .2011. Guide for the care and use of laboratory animals Eighth edition. Washington: The National Academies Press, Washington, D.C. 220 p.

Adikwu, E., and Deo, O.2013. Hepatoprotective Effect of Vitamin C (Ascorbic Acid). Pharmacology and Pharmacy, 4(1): 84-92. doi: 10.4236/pp.2013.41012

Amin, S.N., El-Aidi, A.A., Ali, M.M., Attia, Y.M., and Rashed, L.A. 2015. Modification of hippocampal markers of synaptic plasticity by memantine in animal models of acute and repeated restraint stress: implications for memory and behavior. Neuromolecular Med. 17(2):121-136. doi: 10.1007/s12017-015-8343-0.

Bancroft, J.D., and Gamble, M. 2008. Connective tissue stains. In Theory and Practice of Histological Techniques, sixth edition. Elsevier Health Sciences, Churchill Livingstone, Edinburgh, London, Oxford, New York, Philadelphia, St Louis, Sydney, and Toronto.

Basuroy, S., Leffler, C.W., and Parfenova, H. 2013. CORM-A1 prevents blood-brain barrier dysfunction caused by ionotropic glutamate receptor-mediated endothelial oxidative stress and apoptosis. Am. J. Physiol. Cell Physiol. 304 (11):C1105-15. doi: 10.1152/ajpcell.00023.2013.

Batra, J., and Seth, P.K. 2002. Effect of iron deficiency on developing rat brain. Indian J. Clin. Biochem.17(2):108-14. doi: 10.1007/BF02867982. 
Buijsse, B., Feskens, E.J., Moschandreas, J., Jansen, E.H.,and Jacobs, D.R .2007. Oxidative stress, and iron and antioxidant status in elderly men: differences between the Mediterranean south (Crete) and northern Europe (Zutphen). Eur. J. Cardiovasc. Prev. Rehabil. 14(4): 495-500. doi: 10.1097/HJR.0b013e3280111e41.

Cassiman, D., Denef, C., Desmet, V., and Roskams, T.2001. Human and rat hepatic stellate cell express neutrophils and neutrophin receptors. Hepatology, 33(1): 148-158. doi: 10.1053/jhep.2001.20793.

Chen, J., Shen, H., Chen, C., Wang, W., Yu, S., Zhao, M. et al. 2009. The effect of psychological stress on iron absorption in rats. BMC Gastroenterol. 13: 9-83. doi: 10.1186/1471-230X-9-83.

Chien, L., and Hwang, D.2001.Effects of thermal stress and vitamin C on lipid peroxidation and fatty acid composition in the liver of thornfish Terapon jarbua. Comp. Biochem. Physiol. B Biochem. Mol. Biol.128(1): 9197.

Czech,B., Neumann, I.D., Müller, M., Reber, S.O.,and Hellerbrand, C. 2013. Effect of chronic psychosocial stress on nonalcoholic steatohepatitis in mice. Int. J. Clin. Exp. Pathol. 6(8):1585-93.

Dohare, P., Hyzinski-García, M.C., Vipani, A., Bowens, N.H., Nalwalk, J.W., Feustel, P.J .et al. 2014. The neuroprotective properties of the superoxide dismutase mimetic tempol correlate with its ability to reduce pathological glutamate release in a rodent model of stroke. Free Radic. Biol. Med. 77: 168-82. doi: 10.1016/j.freeradbiomed.2014.08.029.

Ellman, G.L. 1959, Tissue sulfhydryl groups. Arch. Biochem. Biophys. 82: 70-77.

Emsley, R., Dunn, G., and White, I.R. 2010. Mediation and moderation of treatment effects in randomized controlled trials of complex interventions. Stat. Methods Med. Res. 19(3): 237-270. doi: $10.1177 / 0962280209105014$.

Eng, L. F., Ghirnikar, R. S., and Lee, Y.L. 2000. Glial Fibrillary Acidic Protein: GFAP-Thirty-One Years (19692000).Neurochem. Res. 25 (9): 1439-1451.

Ferreira, M., Valenti, V.E., Cisternas, J.R., Ferreira, C., Meneghini, A., Filho, C.F., et al.2011. Memantine effects on liver and adrenal gland of rats exposed to cold stress. Int. Arch. Med. 4(1): 5. doi: 10.1186/1755-7682-4-5. 
Gard, A.L., White, F.P., and Dutton, G.R. 1985.Extra-neural glial fibrillary acidic protein (GFAP) immunoreactivity in perisinusoidal stellate cells of rat liver. J. Neuroimmunol. 8(4-6):359-375

Görg, B., Schliess, F.,and Häussinger, D.2013. Osmotic and oxidative/nitrosative stress in ammonia toxicity and hepatic encephalopathy. Arch. Biochem. Biophys. 536(2):158-63. doi: 10.1016/j.abb.2013.03.010.

Greenwel, P., Geerts, A., Ogata, I., Solis Herruzo, J.A., and Rojkind, M. 1994.Biology and pathobiology. 3rd Ed. Raven Press, New York. pp. 1367-81.

Hassan, S., Syed, S., and Kehar, S. I. 2014. Glial Fibrillary Acidic Protein (GFAP) as a Mesenchymal marker of Early Hepatic Stellate Cells Activation in Liver Fibrosis in Chronic Hepatitis C Infection. Pak. J. Med. Sci. 30(5): 1027-1032. doi: 10.12669/pjms.305.5534.

Jeong, J., and Eide, D.J. 2013. The SLC39 family of zinc transporters.Mol. Aspects Med. 34 (2-3): 612-619. doi: 10.1016/j.mam.2012.05.011.

Johnsen, O., and Eliasson, R. 1987. Evaluation of a commercially available kit for the colorimetric determination of zinc. Int. J. Androl.10 (2): 435-440.

Kageyama, K., Hanada, K., Iwasaki, Y., Sakihara, S., Nigawara, T., Kasckow, J., et al. 2007.Pituitary adenylate cyclase-activating polypeptide stimulates corticotropin-releasing factor, vasopressin and interleukin-6 gene transcription in hypothalamic 4B cells, J. Endocrinol. 195: 199-211.doi: 10.1677/JOE-07-0125

Livak, K.J., and Schmittgen, T.D.2001. Analysis of Relative Gene Expression Data Using Real-Time Quantitative PCR and the 2(-Delta Delta C(T)) Method. Methods, 25: 402-408. doi: 10.1006/meth.2001.1262.

Kiernan, J.A .2001. Histological and Histochemical methods: theory and practice. 3rd ed., Arnold publisher, London, New York and New Delhi. pp. 111-62.

Knecht, K., Michalak, A., Rose, C., Rothstein, J.D., and Butterworth, R.F. 1997. Decreased glutamate transporter (GLT-1) expression in frontal cortex of rats with acute liver failure. Neurosci. Lett. 229(3):201-203. 
Krebs, N.E., and Hambidge, K.M. 2001. Zinc metabolism and homeostasis: the application of tracer techniques to human zinc physiology. Biometals, 14 (3-4): 397-412.

Kumar, A., Garg, R., and Prakash, A. K. 2010. Effect of St. John's Wort (Hypericum perforatum) treatment on restraint stress induced behavioral and biochemical alteration in mice. BMC Complement. Alternat. Med. 7: 1018. doi: $10.1186 / 1472-6882-10-18$

Liu, W., Xu, Z., Deng, Y., Xu, B., Wei, Y., and Yang, T. 2013. Protective effects of memantine against methylmercury-induced glutamate dyshomeostasis and oxidative stress in rat cerebral cortex. Neurotox. Res. 24(3):320-37. doi: 10.1007/s12640-013-9386-3.

Liuzzi, J.P., Lichten, L.A., Rivera, S., Blanchard, R.K., Aydemir, T.B., Knutson, M.D., et al..2005. Interleukin-6 regulates the zinc transporter Zip14 in liver and contributes to the hypozincemia of the acute-phase response. Proc. Natl. Acad. Sci. U.S.A. 102:6843-6848. doi: 10.1073/pnas.0502257102

Lupp, A., Kerst, S.,and Karge, E. 2003. Evaluation of possible pro- or antioxidative properties and of the interaction capacity with the microsomal cytochrome P450 system of different NMDA-receptor ligands and of taurine in vitro. Exp. Toxicol. Pathol. 54:441-448. doi: 10.1078/0940-2993-00280

Maret, W., and Vallee, B.L.1998. Thiolate ligands in metallothionein confer redox activity on zinc clusters. Proc. Natl. Acad. Sci. U.S.A. 95:3478-3482.

Maskos, K., Fernandez-Catalan, C., Huber, R., Bourenkov, G.P., Bartunik, H., Ellestad, G.A., et al. 1998. Crystal structure of the catalytic domain of human tumor necrosis factor-alpha-converting enzyme. Proc. Natl. Acad. Sci. U.S.A. 95(7):3408-12.

McGahan, M.C., Harned, J., Mukunnemkeril, M., Goralska, M., Fleisher, L.,and Ferrell, J.B. 2005. Iron alters glutamate secretion by regulating cytosolic aconitase activity. Am. J. Physiol. Cell Physiol. 288(5): C1117-24. doi: 10.1152/ajpcell.00444.2004

Millán, M., Sobrino, T., Arenillas, J.F., Rodríguez-Yáñez, M., García, M., Nombela, F., et al. 2008. Biological signatures of brain damage associated with high serum ferritin levels in patients with acute ischemic stroke and thrombolytic treatment. Dis. Markers, 25(3):181-8. 
Misra, H.P., and Fridovich, I. 1972. The role of superoxide in the autooxidation of epinephrine and a simple assay for superoxide dismutase. J. Biol. Chem. 247:3170-3175.

Muqbil, I., and Banu, N. 2006. Enhancement of pro-oxidant effect of 7,12-dimethylbenz (a) anthracene (DMBA) in rats by pre-exposure to restraint stress. Cancer Lett. 240(2):213-220. doi: 10.1016/j.canlet.2005.09.008.

Musazzi, L., Treccani, G.,and Popoli, M. 2015. Functional and structural remodeling of glutamate synapses in prefrontal and frontal cortex induced by behavioral stress. Front. Psychiatry, 2015 (6): 60. doi: 10.3389/fpsyt.2015.00060..

Nicolas, G., Bennoun, M.., Devaux, I.., Beaumont, C.., Grandchamp, B., Kahn, A., et al. 2001. Lack of hepcidin gene expression and severe tissue iron overload in upstream stimulatory factor 2 (USF2) knockout mice. Proc. Natl. Acad. Sci. U.S.A. 98: 8780-8785. doi: 10.1073/pnas.151179498

Ohashi, T., Matsui, T., Chujo, M., and Nagao, M.2008. Restraint stress up-regulates expression of zinc transporter Zip14 mRNA in mouse liver. Cytotechnology, 57: 181-185. doi: 10.1007/s10616-008-9148-x

Pekarek, R.S.,and Beisel, W.R. 1971. Characterization of the endogenous mediator(s) of serum zinc and iron depression during infection and other stresses. Proc. Soc. Exp. Biol. Med. 138(2): 728-32.

Popoli, M.., Yan, Z., McEwen, B. S., and Sanacora, G. 2011. The stressed synapse: the impact of stress and glucocorticoids on glutamate transmission. Nat. Rev. Neurosci. 13(1): 22-37. doi: 10.1038/nrn3138.

Quan, M. N., Zhang, N., Wang, Y. Y., Zhang, T., and Yang, Z. 2011. Possible antidepressant effects and mechanisms of memantine in behaviors and synaptic plasticity of a depression rat model. Neuroscience, 182: 8897. doi: 10.1016/j.neuroscience.2011.03.026.

Ramos, E., Kautz, L., Rodriguez, R., Hansen, M., Gabayan, V., Ginzburg, Y., et al.2011.Evidence for Distinct Pathways of Hepcidin Regulation by Acute and Chronic Iron Loading in Mice. Hepatology, 53(4):1333-41. doi: 10.1002/hep.24178.

Riemer, J., Hoepken, H.H., Czerwinska, H., Robinson, S.R., and Dringen, R. 2004. Colorimetric ferrozine-based assay for the quantitation of iron in cultured cells. Anal. Biochem. 331:370-375. doi: 10.1016/j.ab.2004.03.049 
Selye, H. 1955. Stress and disease. Science, 122: 625-631

Stewart, R.K., Dangi, A.., Huang, C., Murase, N., Kimura, S., Stolz, D.B., et al. 2014.A novel mouse model of depletion of stellate cells clarifies their role in ischemia/reperfusion- and endotoxin-induced acute liver injury. J. Hepatol. 60(2):298-305. doi: 10.1016/j.jhep.2013.09.013.

Storto, M., de Grazia, U., Knöpfel, T., Canonico, P.L., Copani, A., Richelmi, P., et al.2000. Selective blockade of mGlu5 metabotropic glutamate receptors protects rat hepatocytes against hypoxic damage. Hepatology. 31(3):649-55. doi: 10.1002/hep.510310315.

Tennakoon, A.H., Izawa, T., Wijesundera, K.K., Murakami, H., Katou-Ichikawa, C., Tanaka, M., et al. 2015. Immunohistochemical characterization of glial fibrillary acidic protein (GFAP)-expressing cells in a rat liver cirrhosis model induced by repeated injections of thioacetamide (TAA). Exp. Toxicol. Pathol. 67(1): 53-63. doi: 10.1016/j.etp.2014.09.008.

Tian, X., Zheng, Y., Li, Y., Shen, Z., Tao, L., Dou, X., et al., 2014. Psychological stress induced zinc accumulation and up-regulation of ZIP14 and metallothionein in rat liver. BMC Gastroenterol. 18: 14:32. doi: 10.1186/1471-230X-14-32.

Tiebosch, M.H. 2014. Antioxidant adaptations in liver fibrogenesis. PhD Dissertation, Rijks Universiteit Groningen, Netherlands. pp. 18-19

Vásquez, B., Sandoval, C., Smith, R.L., and del Sol, M. 2014. Effects of early and late adverse experiences on morphological characteristics of Sprague-Dawley rat liver subjected to stress during adulthood. Int. J. Clin. Exp. Pathol. 7(8):4627-35.

Wang, L., Hou, Y., Yi, D., li, Y., Ding, P., Zhu, H., et al. 2015. Dietary supplementation with glutamate precursor $\alpha$-ketoglutarate attenuates lipopolysaccharide-induced liver injury in young pigs. Amino Acids, 47(7):1309-1318. doi: 10.1007/s00726-015-1966-5.

Wei, C., Zhou, J., Huang, X., and Li, M.2008. Effects of psychological stress on serum iron and erythropoiesis. Int. J. Hematol. 88(1):52-6. doi: 10.1007/s12185-008-0105-4. 
Wills, E.D. 1987. Evaluation of lipid peroxidation in lipids and biological membranes. In Biochemical toxicology: A practical approach. Edited by K. Snell and B. Mullock. IRL Press, Oxford. pp. 127 - 152.

Xiao, J., Ho, C.T., Liong, E.C., Nanji, A.A., Leung, T.M., Lau, T.Y., et al. 2014. Epigallocatechin gallate attenuates fibrosis, oxidative stress, and inflammation in non-alcoholic fatty liver disease rat model through TGF/SMAD, PI3 K/Akt/FoxO1, and NF-kappa B pathways. Eur. J. Nutr. 53(1): 187-99. doi: 10.1007/s00394013-0516-8.

Xu, J.K., Hiroshi, K., Zheng, J.J., Jiang, T., and Yao, X.S. 2006. Protective effect of tanshinones against liver injury in mice loaded with restraint stress. Acta Pharmaceutica Sinica, 41(7):631-635.

Ye, L., Huang, Y., Zhao, L., Li, Y., Sun, L., Zhou, Y., et al. 2013. IL-1 $\beta$ and TNF- $\alpha$ induce neurotoxicity through glutamate production: a potential role for neuronal glutaminase. J. Neurochem. 125(6):897-908. doi: 10.1111/jnc. 12263 .

Yuen, E. Y., Liu, W., Karatsoreos, I. N., Feng, J., McEwen, B. S., and Yan, Z. 2013. Acute stress enhances glutamatergic transmission in prefrontal cortex and facilitates working memory. . Proc. Natl. Acad. Sci. U.S.A. 106(33): 14075-14079. doi: 10.1073/pnas.0906791106.

Yuen, E.Y., Liu, W., Karatsoreos, I.N., Ren, Y., Feng, J., McEwen, B.S., et al. 2011. Mechanisms for acute stressinduced enhancement of glutamatergic transmission and working memory. Mol. Psychiatry, 16: 156-170. doi: 10.1038/mp.2010.50.

Zelena, D., Mergl, Z., and Makara, G. B. 2005. Glutamate agonists activate the hypothalamic-pituitary-adrenal axis through hypothalamic paraventricular nucleus but not through vasopressinerg neurons. Brain Res. 1031: 185193. doi: $10.1016 /$ j.brainres.2004.10.034

Zhao, M., Chen, J., Wang, W.W., Wang, L., Ma, L., Shen, H., et al.2008.Psychological stress induces hypoferremia through the IL-6-hepcidin axis in rats. Biochem. Biophys. Res. Commun. 373:90-93. doi: 10.1016/j.bbrc.2008.05.166.

Zhao, N., Gao, J., Enns, C.A., and Knutson, M.D. 2010. ZRT/IRT-like protein 14 (ZIP14) promotes the cellular assimilation of iron from transferrin. J. Biol. Chem. 285(42):32141-50. doi: 10.1074/jbc.M110.143248. 


\section{-TABLES:}

Table 1: primers sequence for all studied genes:

\begin{tabular}{|l|l|}
\hline Gene & Primers sequence \\
\hline Metallothionin & $\begin{array}{l}\text { F: 5'-ACTGCCTTCTTGTCGCTTA-3' } \\
\text { R: 5'-TGGAGGTGTA-CGGCAAGACT-3' }\end{array}$ \\
\hline Hepcidin & F:5-CACAGCAGAACAGAAGGCATG-3 \\
& R:5- CTTCTGCTGTAAATGCTGT-3 \\
\hline Zip14 & $\begin{array}{l}\text { Forward:5'-GTCTGGCCTTTGGCATCCT-3' } \\
\text { reverse 5'-AGGGAACATATCAGCCAGAGAAAT-3'; }\end{array}$ \\
\hline Beta-actin & $\begin{array}{l}\text { forward 5'-TGTTGTCCCTGTATGCCTCT-3' } \\
\text { reverse 3'-TAATGTCACGCACGATTTCC-5' }\end{array}$ \\
\hline
\end{tabular}

ZIP14= zinc transporter ZRT/IRT-like Protein 14 
Table (2): Biochemical Parameters measured in the studied groups:

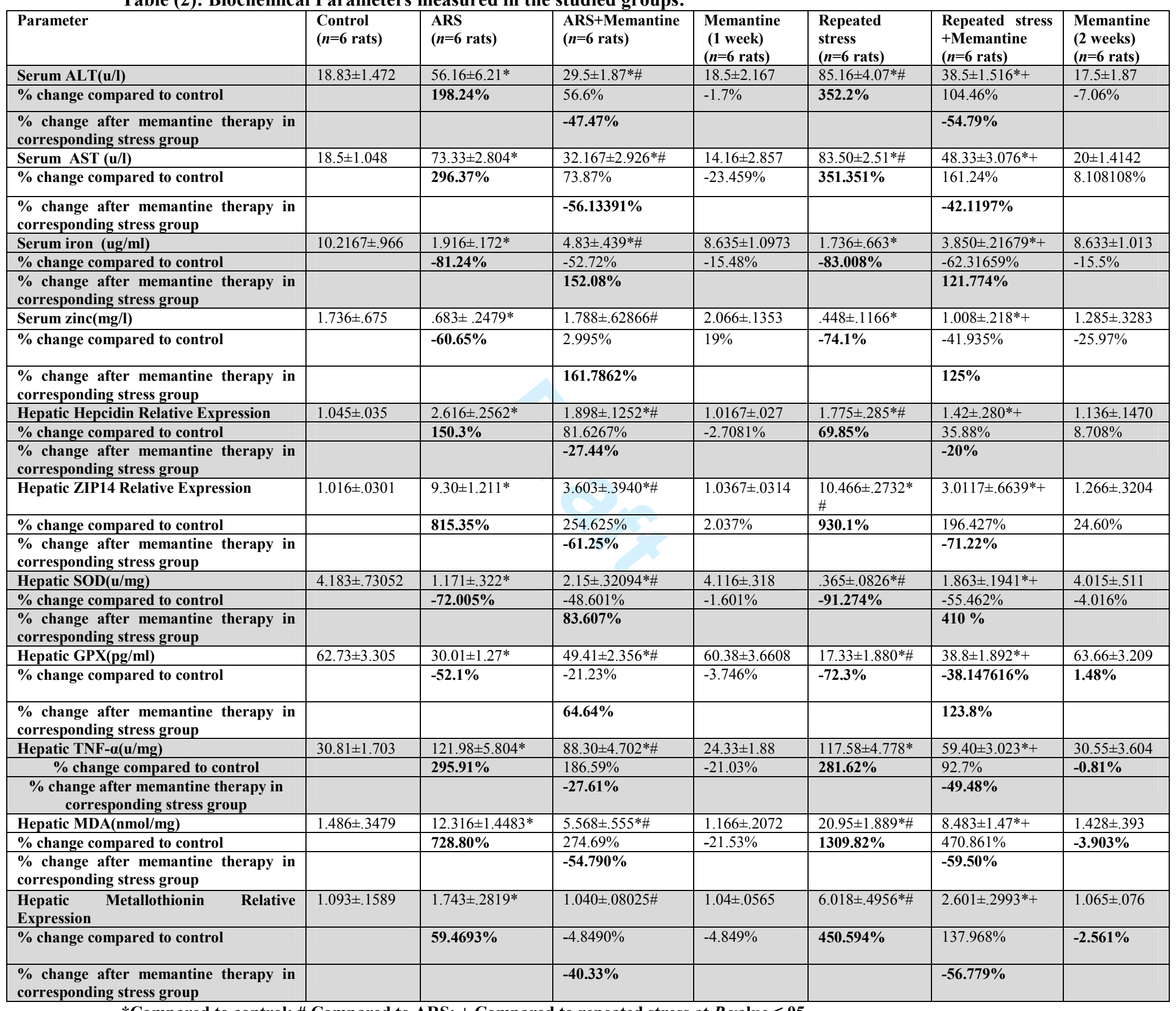

*Compared to control; \# Compared to ARS; + Compared to repeated stress at $P$ value $\leq .05$

ARS=Acute restraint stress; $A L T=$ alanine transferase; $A S T=$ Aspartame transferase; $\mathbf{S O D}=$ Superoxide Dismutase; GPX= glutathione peroxidase transporter ZRT/IRT-like Protein 14 TNF- $\alpha=$ tumor necrosis factor- $\alpha$; MDA= malondialdehyde; ZIP14 $=$ zinc 
Table 3: Mean \pm SD of area of foci of lost architecture, area $\%$ of collagen fibers, area $\%$ of GFAP and $\%$ of synaptophysin immunoexpression in the studied groups

\begin{tabular}{|c|c|c|c|c|c|c|c|}
\hline & $\begin{array}{c}\text { Control } \\
(n=6 \text { rats })\end{array}$ & $\begin{array}{c}\text { ARS } \\
(n=6 \text { rats })\end{array}$ & $\begin{array}{c}\text { ARS+Memantine } \\
(n=6 \text { rats })\end{array}$ & $\begin{array}{c}\text { Memantine } \\
(1 \text { week }) \\
(n=6 \text { rats })\end{array}$ & $\begin{array}{l}\text { Repeated stress } \\
\quad(n=6 \text { rats })\end{array}$ & $\begin{array}{c}\text { Repeated } \\
\text { stress } \\
+ \text { Memantine } \\
\text { (n=6 rats) }\end{array}$ & $\begin{array}{c}\text { Memantine } \\
(2 \text { weeks) } \\
(n=6 \text { rats })\end{array}$ \\
\hline $\begin{array}{l}\text { Area of foci of lost } \\
\text { architecture }\end{array}$ & - & $\begin{array}{l}\text { 1574.19士 } \\
331.23^{*}\end{array}$ & $407.49 \pm 66.11 \#$ & - & $3230.67 \pm 223.08 *$ & $303.89 \pm 51.05+$ & - \\
\hline $\begin{array}{l}\text { \% change compared } \\
\text { to } \quad \text { corresponding } \\
\text { stress group }\end{array}$ & & & $-74.11 \%$ & & & $-90.5 \%$ & \\
\hline $\begin{array}{l}\text { Area\% of collagen } \\
\text { fibers }\end{array}$ & $1.36 \pm 0.21$ & $5.79 \pm 0.80 *$ & $1.93 \pm 0.76 \#$ & $1.45 \pm .6$ & $9.98 \pm 1.86 * \#$ & $2.03 \pm 0.16+$ & $1.68 \pm 0.16$ \\
\hline $\begin{array}{l}\text { \% } \text { change compared } \\
\text { to } \quad \text { corresponding } \\
\text { stress group }\end{array}$ & & & $-66.66 \%$ & & & $-79.65 \%$ & \\
\hline $\begin{array}{l}\text { Area \% of GFAP } \\
+ \text { ve cells }\end{array}$ & - & $5.20 \pm 1.99 *$ & $1.58 \pm 0.76 \#$ & - & $12.16 \pm 1.65 * \#$ & $1.76 \pm 0.16+$ & - \\
\hline $\begin{array}{l}\text { \% change compared } \\
\text { to } \\
\text { stress group }\end{array}$ & & & $-69.61 \%$ & & & $-85.52 \%$ & \\
\hline $\begin{array}{lrr}\text { Area } & \% & \text { of } \\
\text { Synaptophysin } & + \text { ve } \\
\text { cells } & \end{array}$ & - & $4.98 \pm 1.02 *$ & $1.03 \pm 0.19 \#$ & - & $13.11 \pm 2.50 * \#$ & $1.91 \pm 0.32+$ & - \\
\hline $\begin{array}{l}\text { \% } \text { change compared } \\
\text { to } \\
\text { stress group }\end{array}$ & & & $-79.31 \%$ & & & $-85.43 \%$ & \\
\hline
\end{tabular}

*Compared to control; \# Compared to ARS; + Compared to repeated stress at $P$ value $\leq .05$ 


\section{-LEGENDS:}

Fig. 1: Photomicrographs of sections in the liver of rats in a: AS group showing two areas, a large one (big *) and a small one $($ small *) with lost architecture $(\mathbf{H \& E}, \mathbf{x 1 0 0})$. b: Higher magnification of the previous figure showing multiple pale hepatocytes (arrows) and many hepatocytes with basophilic cytoplasm (arrowheads) around congested veins (*). Note multiple Kupffer cells (wavy arrow) (H\&E, x200). c: AS and M group showing a small area $\left(^{*}\right)$ with lost architecture. Note congested veins (c) in and around the mass (H\&E, x100). d: Higher magnification of the previous figure showing multiple vacuolated hepatocytes with dark nuclei (arrow) and some hepatocytes with pale cytoplasm (arrowhead). Note congested veins (c) in and around the mass (H\&E, x200).

Fig. 2: Photomicrographs of sections in the liver of rats in a: RS group showing an extended area (*) with lost architecture constituting a mass of residual hepatocytes (arrowhead) (H\&E, x100). b: Higher magnification of the previous figure showing cellular debris (arrows) surrounding a mass of hepatocytes with nuclear margination (arrowhead) (H\&E x100). c: RS and M group demonstrating a localized area (*) with lost architecture (H\&E x100). d: M group showing typical architecture. Note a congested vein (c) (H\&E x100).

Fig. 3: Photomicrographs of sections in the liver of rats in a: Control group showing dense collagen fibers in a portal area (arrow). b: AS group showing dense collagen fibers in a portal area extending (arrows) among the surrounding hepatocytes. c: AS and M group showing dense collagen fibers (arrows) localized to a portal area. d: RS group showing extensive collagen fibers in a portal area extending (arrows) among the surrounding hepatocytes. Note obviously congested veins (*). e: RS and M group showing dense collagen fibers in a portal area with minimal extension (arrows) among the hepatocytes. Note a less congested vessel (*). f: M group showing dense collagen fibers restricted to two portal areas (arrows). Note less congested vessels (*). (Masson's trichrome x200). 
Fig. 4: Photomicrographs of sections in the liver of rats in a: Control group showing -ve immunoexpression. b: AS group showing multiple GFAP +ve cells (arrows) among the hepatocytes. c: AS and M group showing fewer GFAP +ve cells (arrows) among the hepatocytes. d: RS group showing more numerous GFAP + ve cells (arrows) among the hepatocytes. e: RS and M group showing fewer GFAP +ve cells (arrows) among the hepatocytes. f: M group showing -ve immunoexpression (GFAP immunostaining x200).

Fig. 5: Photomicrographs of sections in the liver of rats in a: Control group showing -ve immunoexpression. b: AS group showing multiple GFAP +ve cells (arrows) among the hepatocytes surrounding a portal area. c: AS and M group showing fewer GFAP + ve cells (arrows) among the hepatocytes surrounding a portal area. d: RS group showing more numerous GFAP + ve cells (arrows) among the hepatocytes surrounding a portal area. e: RS and M group showing fewer GFAP + ve cells (arrows) among the hepatocytes surrounding a portal area. f: M group showing -ve immunoexpression (Synaptophysin immunostaining x200). 
Figures

Fig.1

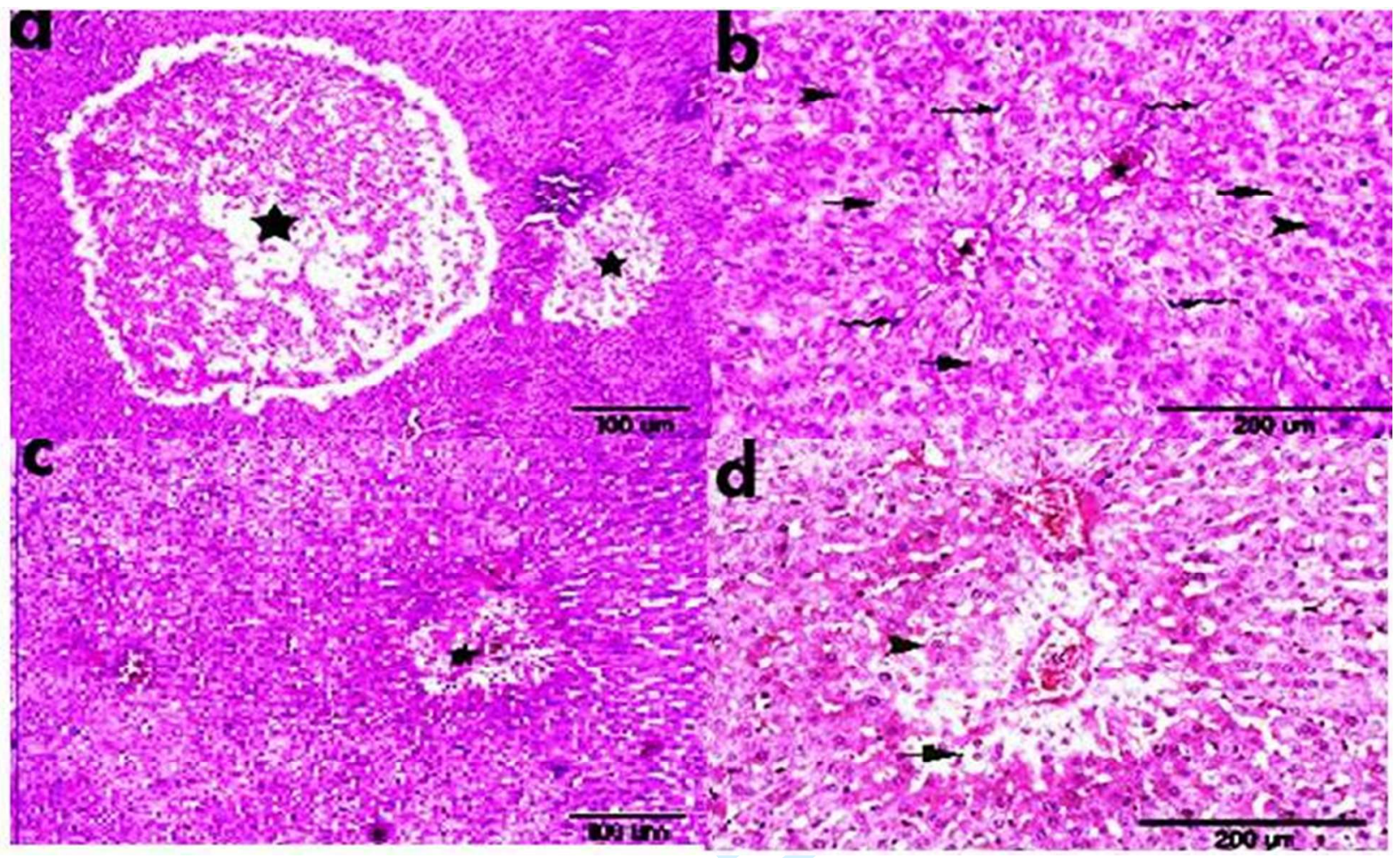


Fig.2

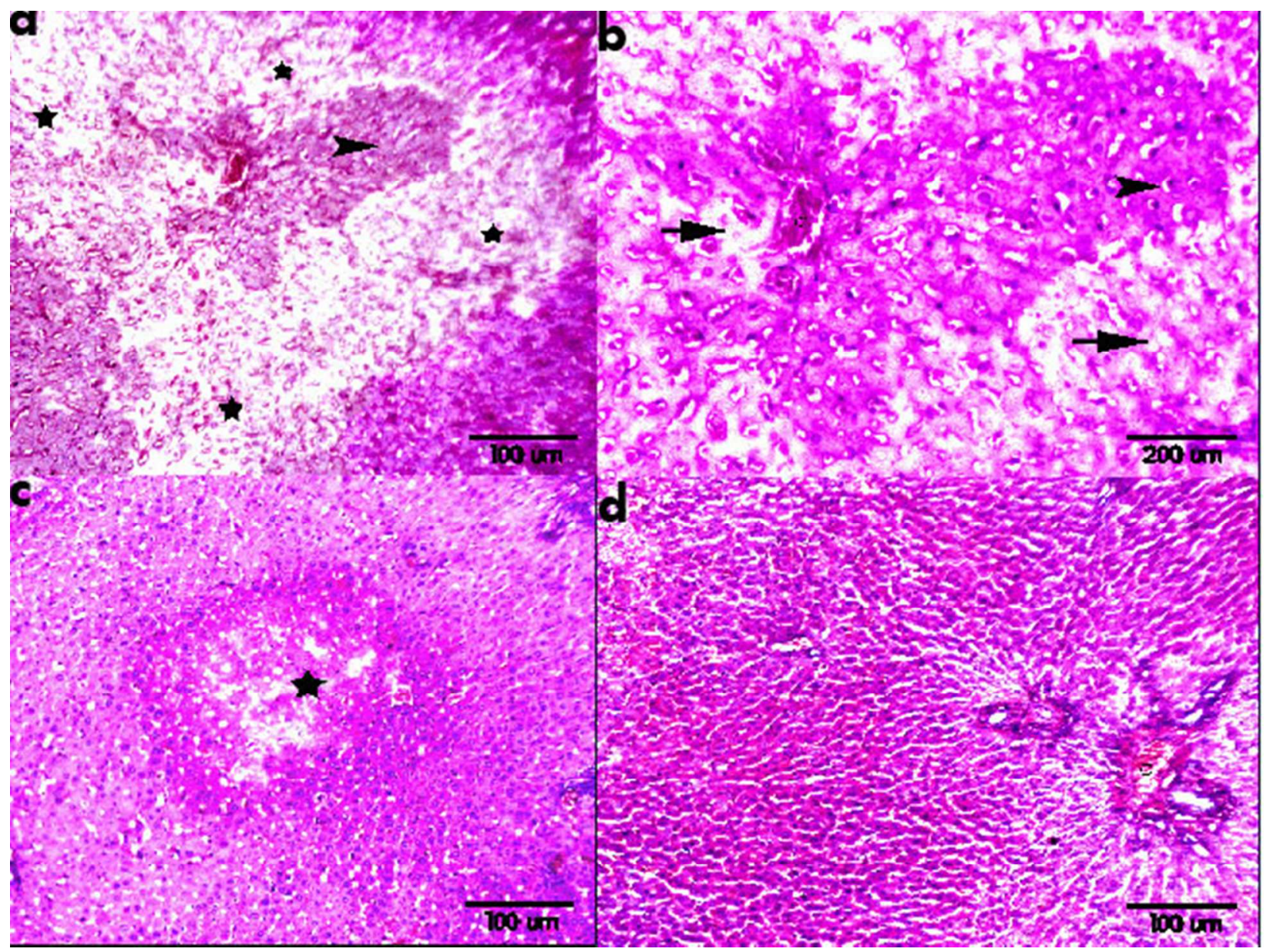


Fig.3

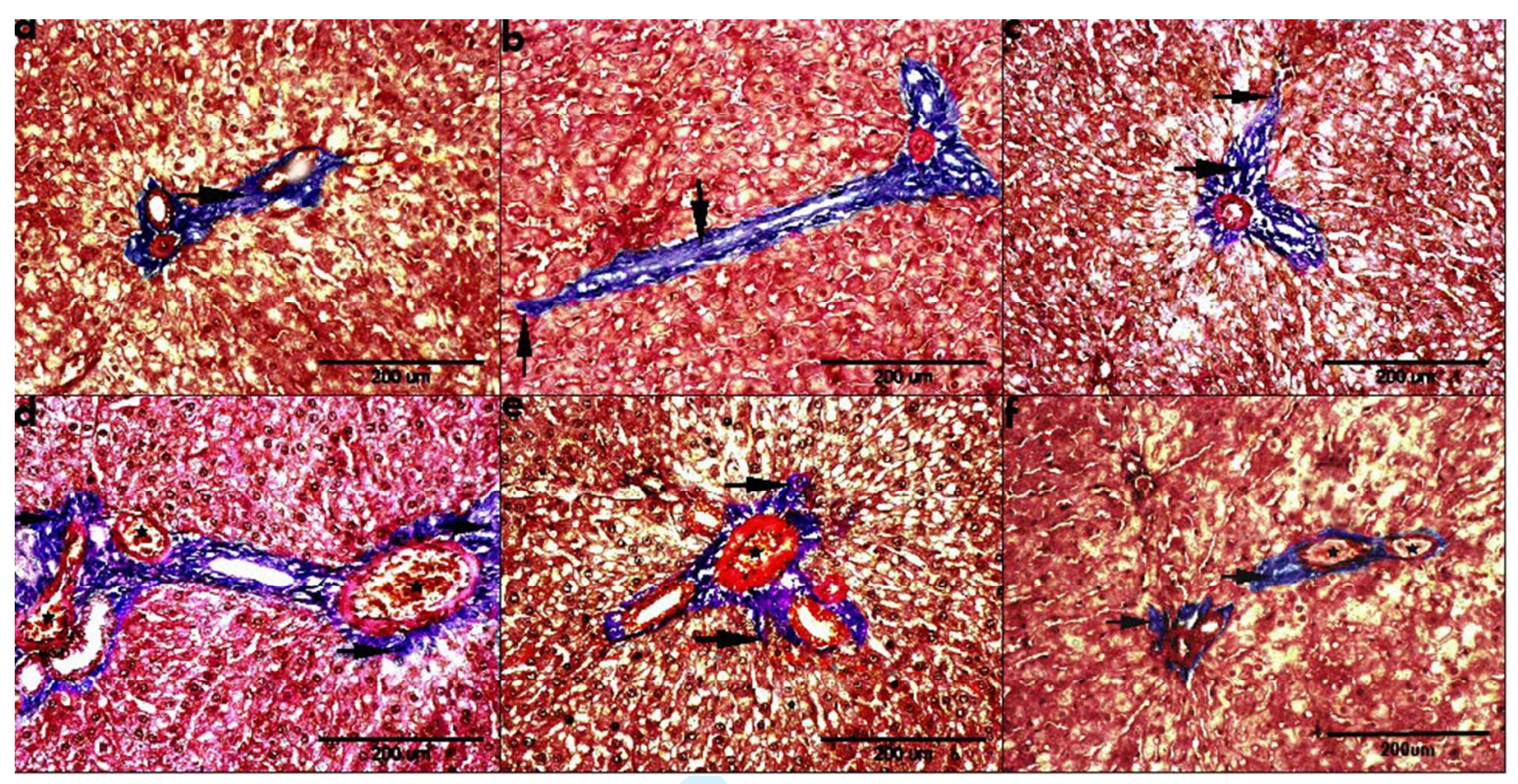


Fig 4

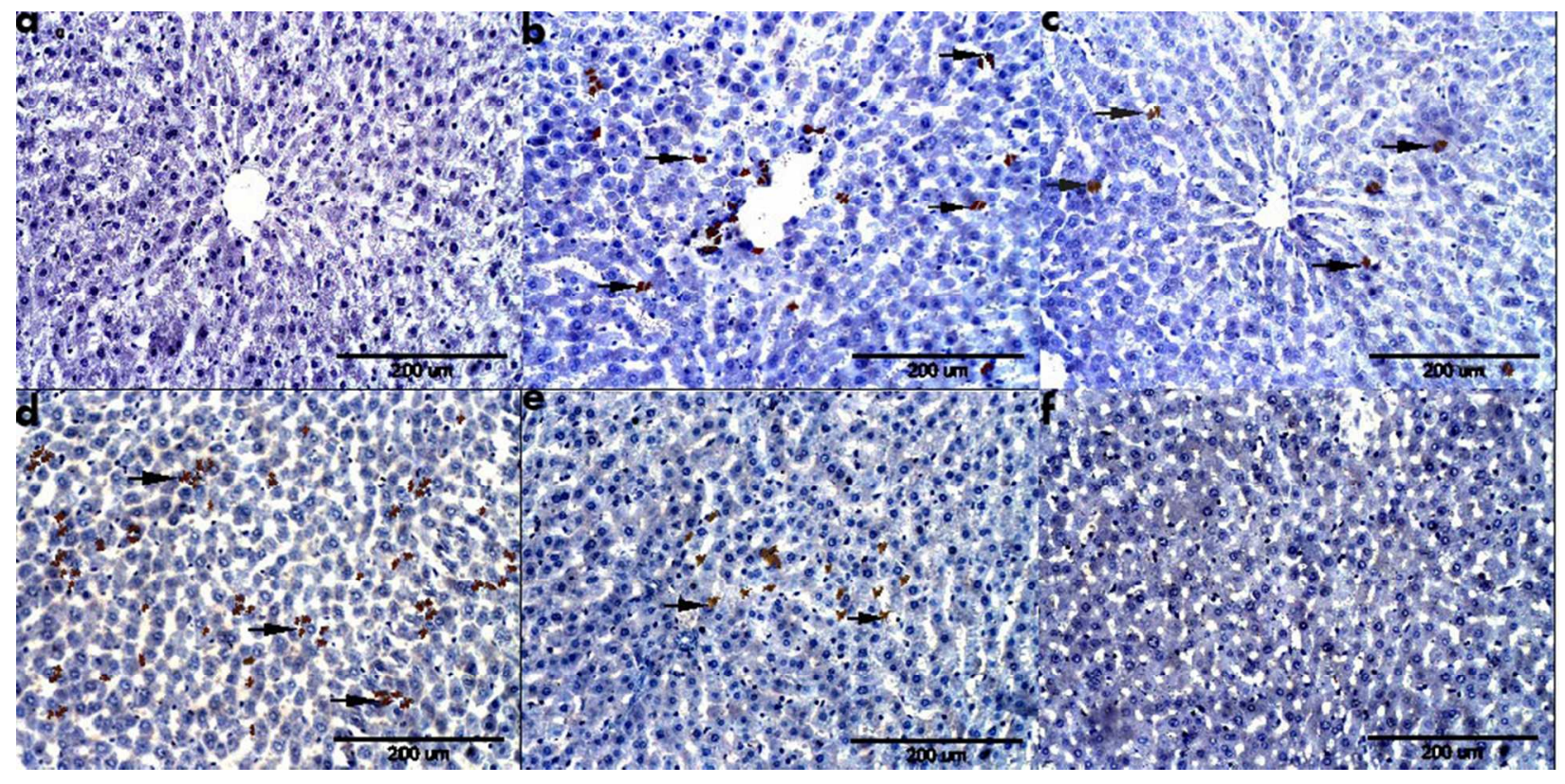


Fig 5

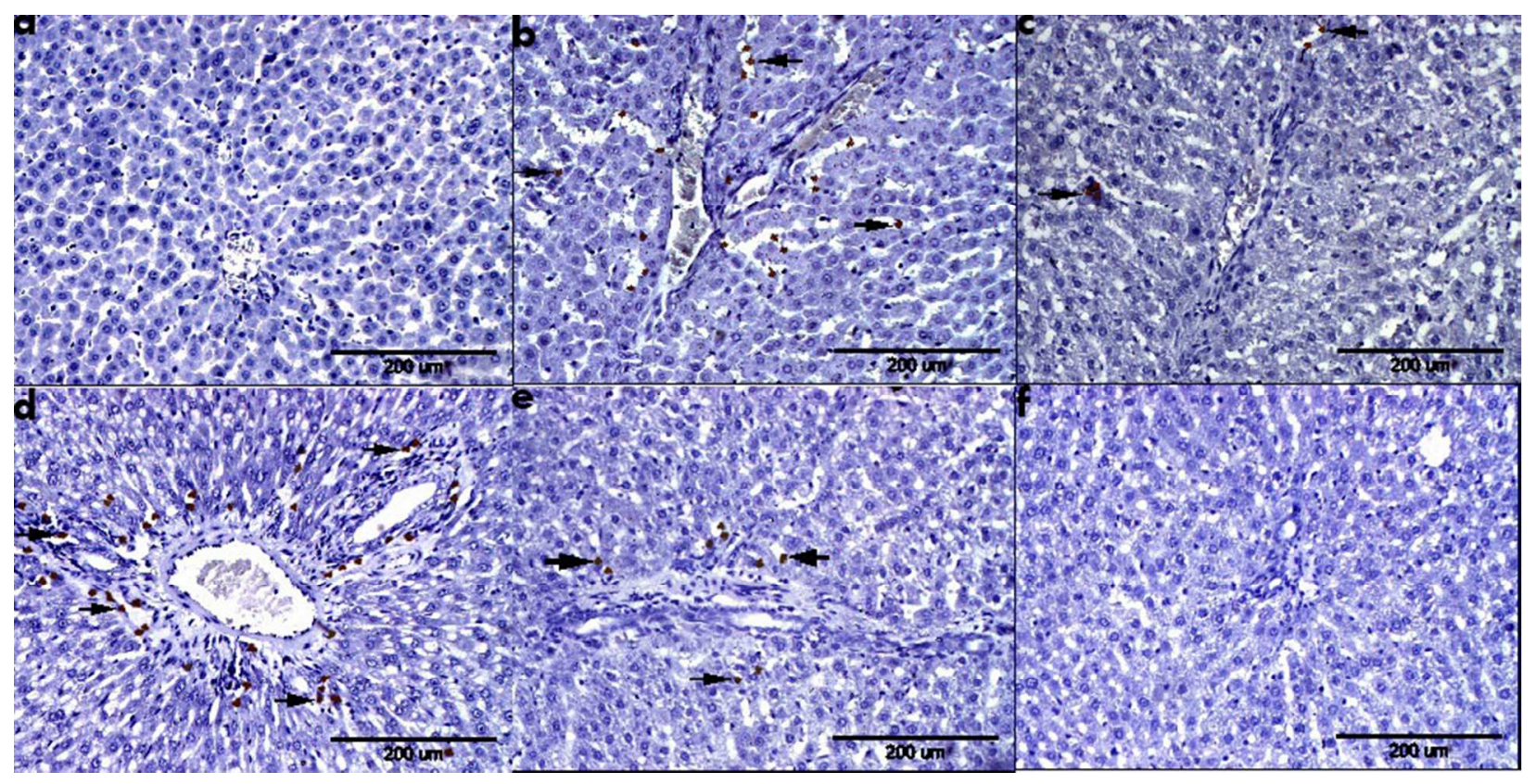

https://mc06.manuscriptcentral.com/cjpp-pubs 